Cakrawala Dini: Jurnal Pendidikan Anak Usia Dini | p-ISSN 2087-I317 | e-ISSN 2621-8321

Vol. 马. No.2 November 2018 | Hal IID-124

\title{
PENGEMBANGAN MEDIA PEMBELAJARAN KOMIK TEMA ALAM SEMESTA UNTUK ANAK
}

\author{
Rizki Apriyani ${ }^{1}$, Sri Sumarni ${ }^{2}$, Rukiyah ${ }^{3}$ \\ Program Studi Pendidikan Anak Usia Dini, FKIP, \\ Universitas Sriwijaya
}

\begin{abstract}
This study aims to produce comic learning media of valid and practical universe theme, but does not test the potential effect of the media. The subject of this research is a child of group B12 and the object is a comic book of the universe theme. The development of this comic media uses a combination of Rowntree's development model and Tessmer's evaluation. The Rowntree development model consists of three stages, namely the planning, development and evaluation phase. At the evaluation stage, the formative evaluation proposed by Tessmer consists of five stages: self evaluation, expert review, one-to-one evaluation, small group evaluation and field test. However, since this study only tested the validity and practicality, this study only reached the small group stage. Observation techniques are used at the time of data collection. The result of the average validation of expert review obtained is very valid in 3.72. In one to one evaluation stage, the average of observation result in subtheme of natural objects is $81,3 \%$ (category is growing very well), Subtheme of sky objects is 79,2\% (category is growing as expected), subthemes of natural phenomena is $79.2 \%$ (category is growing as expected). The small group evaluation stage showed that the average observation on subtheme of natural objects is $86.8 \%$ (category is growing very well), subtheme of sky objects is $83.3 \%$ (category is growing very well), subthemes of natural phenomena is $89,3 \%$ (category is growing very well). So From all stages that have been done then it can be concluded that the comic media theme of the universe declared valid and practical for children.
\end{abstract}

Keyword: Comic as media, theme of the universe, Children Group B

\begin{abstract}
Abstrak: Penelitian ini bertujuan untuk menghasilkan media pembelajaran komik tema alam semesta yang valid dan praktis, tetapi tidak menguji efek potensial dari media tersebut . Subjek penelitian ini adalah anak kelompok B12 dan objeknya adalah buku komik tema alam semesta. Pengembangan media komik ini menggunakan kombinasi model pengembangan Rowntree dan evaluasi Tessmer. Model pengembangan Rowntree terdiri dari tiga tahap, yaitu tahap perencanaan, pengembangan dan tahap evaluasi. Pada tahap evaluasi dilakukan evaluasi formatif yang dikemukakan oleh Tessmer terdiri dari lima tahap, yaitu tahap self evaluation, expert review, one-to-one evaluation, small group evaluation dan field test. Namun karena penelitian ini hanya menguji kevalidan dan kepraktisan saja, maka penelitian ini hanya sampai pada tahap small grup. Teknik observasi digunakan pada saat pengumpulan data. Hasil nilai rata-rata validasi expert review yang diperoleh termasuk dalam kategori sangat valid yaitu sebesar 3,72. Pada tahap one to one evaluation didapatkan rata-rata hasil observasi pada subtema benda-benda alam sebesar 81,3\% (kategori berkembang sangat baik), Subtema benda-benda langit sebesar 79,2\% (kategori berkembang sesuai harapan), Subtema bencana alam sebesar 79,2\% (kategori berkembang sesuai harapan). Tahap small group evaluation didapatkan hasil rata-rata observasi pada subtema benda-benda alam sebesar 86,8\% (kategori berkembang sangat baik), subtema benda-benda langit sebesar $83,3 \%$ (kategori berkembang sangat baik), subtema gejala alam sebesar 89,3\% (kategori berkembang sangat baik). Jadi Dari semua
\end{abstract}

\footnotetext{
'Mahasiswa PAUD, FKIP, Universitas Sriwijaya, Email: rizkiapriyanil23旬gmail.com

${ }^{2}$ Dosen PAUD, FKIP, Universitas Sriwijaya, Email: yik5 Sunsri国yahoo.co.id

${ }^{3}$ Dosen PAUD, FKIP, Universitas Sriwijaya,, Email: Rukiyahunsri国gmail.com
} 
tahap yang telah dilakukan, dapat disimpulkan bahwa media komik tema alam semesta dinyatakan valid dan praktis bagi anak.

Kata Kunci: Media Komik, Tema Alam Semesta, Anak Kelompok B

\section{PENDAHULUAN}

Media adalah bagian yang tidak terpisahkan dari proses belajar mengajar demi tercapainya tujuan pendidikan pada umumnya dan tujuan pembelajaran di sekolah pada khususnya. Senada dengan Azar yang dikutip oleh Asmariani (2016) bahwa media pembelajaran pendidikan secara umum dapat diartikan sebagai sarana atau prasarana yang dipergunakan untuk membantu tercapainya tujuan pembelajaran. Jika dikaitkan dengan pendidikan anak usia dini, maka media pembelajaran berarti segala sesuatu yang dapat dijadikan bahan (software) dan alat (hardware) untuk bermain yang membuat AUD mampu memperoleh pengetahuan, keterampilan, dan menentukan sikap. Salah satu jenis media yang dapat digunakan adalah media cetak seperti buku, majalah dll. Untuk itu guru harus memiliki pengetahuan dan pemahaman yang cukup tentang media pembelajaran. Di samping mampu menggunakan alatalat yang tersedia, guru juga dituntut untuk dapat mengembangkan keterampilan membuat media pembelajaran yang akan digunakannya apabila media tersebut belum tersedia.

Alam semesta adalah salah satu tema pembelajaran yang ada di semester genap. Berisi tiga macam subtema yaitu benda-benda alam, benda-benda langit, dan gejala alam, lalu disetiap subtema terdapat sub-sub tema. Pada subtema benda-benda alam terdiri dari jenis-jenis benda alam yaitu tanah, air, pasir, batu, besi, emas, perak dan manfaat bendabenda alam. Pada subtema benda-benda langit terdiri dari jenis benda-benda langit yaitu matahari, bulan, bintang dan manfaat benda-benda langit. Pada subtema gejala alam terdiri dari macammacam gejala alam yaitu siang, malam, banjir, gunung meletus, tanah lonsor, ombak, pelangi, petir, hujan, gempa bumi.

Berdasarkan hasil observasi dan analisis media yang telah saya lakukan di tiga TK, yaitu TK Negeri Pembina 1 Palembang, TK Anggrek Delima, dan PAUD Mawar, media yang digunakan untuk tema alam semesta masih kurang. Di TK Anggrek Delima,hanya menggunakan buku kegiatan siswa saja, selebihnya guru hanya menggambar atau menuliskannya di papan tulis. Di TK Negeri Pembina 1 Palembang media yang digunakan hanya kartu kata, kartu huruf,majalah anak dan juga gambargambar yang diprint di kertas A4 saja, sehingga media gambarnya terpisahpisah. Dan di PAUD Mawar media yang digunakan hanya menggunakan buku majalah dan gambar-gambar saja. Jadi dari ketiga TK tersebut, kegiatan pembelajarannya hanya mengerjakan majalah/buku kegiatan siswa, mengamati gambar, menjiplak huruf, dan meniru tulisan, sehingga anak-anak menjadi bosan dalam pembelajaran pada aspek bahasa terutama pada materi alam semesta. Sehingga dibutuhkan media yang inovatif dan menarik yang dapat membangkitkan semangat anak-anak dalam kegiatan pada tema alam semesta.

Hasil observasi dan analisis media hanya melibatkan satu pihak yaitu observer, maka setelah saya sebagai observer telah melakukan analisis media, saya melakukan wawancara dengan guru yang ada di kelas. Di TK Anggrek Delima saya mewawancari Ibu Maryama selaku guru kelas alpukat, di TK Negeri Pembina 1 Palembang saya mewawancarai Ibu Rasiyem selaku guru rombel B12, dan di PAUD Mawar saya mewawancarai Ibu Halimah selaku guru kelas B2. Hasil wawancara dengan tiga guru kelas di tiga TK tersebut membuktikan bahwa media 
untuk pembelajaran alam semesta memang masih kurang, di majalah/ buku kegiatan siswa pun ada materi alam semesta yang tidak tersedia. Jadi untuk menutupi kekurangan tersebut menggunakan gambar yang di print di kertas A4 atau hanya menuliskan dan menggambarnya di papan tulis saja. Sehingga perlu untuk mengembangkan media baru.

Salah satu media pembelajaran berbentuk cetak yang inovatif dan menyenangkan yaitu berupa komik. Komik merupakan sebuah terobosan media pembelajaran yang inovatif dan kreatif dalam proses peningkatan keterampilan berbahasa pada PAUD. Pendapat ini sama hal nya yang dikatakan oleh Sudarti (2017) bahwa komik memiliki beberapa kelebihan yaitu dapat menambah pembendaharaan kata dan dapat mengembangkan minat baca pada anak. Berisi gambar-gambar dengan warna yang menarik, sehingga membangkitkan semangat anak-anak dalam proses kegiatan bercerita. Senada dengan penelitian yang dilakukan oleh Setiawan (2013) yang berjudul "Peningkatan Keterampilan Bercerita Menggunakan Media Komik Strip Bermuatan Nilai-Nilai Pendidikan Karakter Pada Siswa Kelas II MI Rifaiyah Limpung Batang" dari hasil penelitian menunjukkan bahwa dengan menggunakan media komik strip bermuatan nilai-nilai pendidikan karakter dapat meningkatkan keterampilan bercerita yaitu pada siklus I nilai rata-rata klasikal sebesar 63,52 sedangkan pada siklus II nilai rata-rata klasikal sebesar 79,41 .

Melalui komik, nilai-nilai pendidikan juga dapat dikenalkan sejalan dengan materi yang disampaikan sesuai tema pembelajarannya. Salah satu tema pembelajaran disemester genap yang dapat digunakan dalam pembelajaran menggunakan komik adalah tema alam semesta. Karena tema alam semesta memiliki cukup banyak cakupan materi yang bisa dibahas dan dikembangkan menjadi berbagai cerita yang bermanfaat bagi anak. Berisi gambar-gambar yang lucu, berwarna-warni, dan dilengkapi dengan materi pembelajaran alam semesta yang ringan dengan gaya bahasa yang santai, maka akan memudahkan anak didik dalam memahami isi komik tersebut. Sehingga materi pembelajaran seperti pelangi, matahari, hujan dll dapat mudah dipahami oleh anak.

Namun pada kenyataannya media pembelajaran di TK berbentuk komik belum pernah ditemui atau belum ada, di TK Anggrek Delima, PAUD Mawar, dan TK Negeri Pembina 1 Palembang pun belum pernah menggunakan media komik.Padahal salah satu kelebihan dari komik seperti penelitian yang dilakukan oleh Thorndike yang dikutip oleh Daryanto (2016:146), diketahui bahwa anak yang membaca komik lebih banyak maka sama dengan membaca buku- buku pelajaran dalam setiap tahunnya, hal ini berdampak pada kemampuan membaca siswa dan penguasaan kosa kata jauh lebih banyak dari siswa yang tidak menyukai komik.

Berdasarkan analisis kebutuhan dan wawancara di atas bahwa komik sangat penting dikembangkan sebagai media pembelajaran. Maka untuk mengantisipasi masalah kemampuan berbicara dan kurangnya media pembelajaran yang inovatif pada anak diperlukan suatu media pembelajaran yang berguna dan inovatif untuk mengasah kemampuan berbicara mereka yaitu komik. Berdasarkan latar belakang mengenai permasalahan diatas, peneliti mengajukan judul penelitian: Pengembangan Media Pembelajaran Komik Tema Alam Semesta Untuk Anak Kelompok B Di Tk Negeri Pembina 1 Palembang

\section{METODOLOGI}

PENELITIAN

Penelitian ini adalah penelitian pengembangan atau Development Research yang bertujuan untuk menghasilkan media pembelajaran 
berbentuk buku komik tema alam semesta. Penelitian pengembangan ini menggunakan model Rowntree untuk menghasilkan dan menguji produk dalam mengembangkan media pembelajaran. Sedangkan pada tahap evaluasi materi digunakan evaluasi formatif tessmer. Menurut Prawiradilaga (2015: 45) Model Rowntree berisi 3 fase tahapan, yaitu tahap perencanaan, tahap pengembangan dan tahap evaluasi atau penilaian.

Prosedur Penelitian

\section{Tahap Perencanaan}

Analisis dilakukan untuk mengidentifikasi masalah dan mengetahui karakteristik murid. Langkah-langkah analisis ini sebagai berikut

Analisis Media, peneliti menganalisis media yang dipakai murid sekarang sebagai bahan masukan untuk mengembangkan media baru atau mengembangkan yang telah ada. Peneliti menganalisis kelebihan dan kekurangan sehingga hasil analisis dapat digunakan untuk menyempurnakan media yang akan dikembangkan.

Analisis Materi, pada tahap ini dilakukan analisis terhadap materi yang diberikan oleh guru kepada murid. Selanjutnya mengumpulkan data yang dapat digunakan sebagai referensi pendukung untuk mengembangkan media pembelajaran. Referensi dapat berupa buku, jurnal, situs internet baik yang cetak maupun dalam bentuk soft file.

Wawancara Guru Kelas, pada langkah ini dilakukan wawancara terhadap guru. Hal ini dilakukan untuk mengetahui masalah yang ada dilapangan sehubungan dengan ketersediaan media pembelajaran dan kegiatan belajar mengajar.

\section{Tahap Pengembangan}

Tahap Pertama adalah Pengembangan materi, merupakan penentuan isi cerita pada buku komik tema alam semesta. Materi harus sesuai dengan Buku Panduan Pendidik
Kurikulum 2013 PAUD Anak Usia B (56 Tahun).

Setelah menyusun isi cerita, langkah selanjutnya adalah memproduksi prototipe. Materi yang telah disusun, akan di konversi kedalam bentuk naskah cerita, dari naskah cerita inilah kemudian akan diilustrasikan dalam bentuk gambar. Senada dengan Juliati (2014) bahwa komik dikenal sebagai cerita bergambar (cergam) atau sebagai cerita yang didukung oleh serangkaian gambar berurutan yang terbentuk dari sebuah naskah cerita.Gambar hasil ilustrasi dari cerita kemudian akan diberikan teks percakapan antar tokoh sehingga cerita pada setiap gambar saling berhubungan dalam bentuk peristiwa sehari-hari atau seperti dikehidupan sehari-hari sesuai dengan tema alam semesta seperti air, tanah, batu,dll. Dalam hal ini peneliti akan mengembangkan satu buku komik tema alam semesta dengan 3 subtema yaitu : (1) Benda-benda alam. (2) Benda-benda langit. (3) Bencana alam. Buku komik ini disesuaikan dengan tema yang ada di semester dua. Hasil dari keseluruhan tahap pengembangan ini disebut Prototipe 1.

\section{Tahap Evaluasi}

Tahap evaluasi ini bertujuan untuk menganalisis kevalidan dan keefektifan media pembelajaran yang kita implementasikan. Tahap evaluasi ini menggunakan evaluasi Tessmer, dengan tahapan berikut:

Self evaluation, pada tahap ini peneliti menilai sendiri desain media pembelajaran prototipe 1 yang dikembangkan. Peneliti akan melakukan revisi sampai prototipe 1 tergolong baik. Selain mengevaluasi sendiri juga dapat meminta saran kepada teman sejawat atau dosen pembimbing untuk memberi saran dan

komentar.

Expert review, pada tahap ini, prototipe akan divalidasi oleh ahli. Dalam hal ini, ahli media dan ahli materi.Saran- 
saran dari para ahli ditulis pada lembar validasi sebagai bahan revisi.

One-to-one evaluation, dalam tahap ini, prototipe 1 diujicobakan kepada tiga orang siswa non subjek penelitian.Prototipe 1 yang telah direvisi melalui tahap expert review dan one-toone selanjutnya dinamakan prototipe 2 . Prototipe 2 akan diujicobakan ke tahap small

group.

Small group, Setelah melalui tahap expert review dan one-to-one, dilanjutkan pada tahap small group. Pada tahap ini, prototipe 2 diujicobakan pada small group dengan sembilan orang siswa non subjek penelitian.

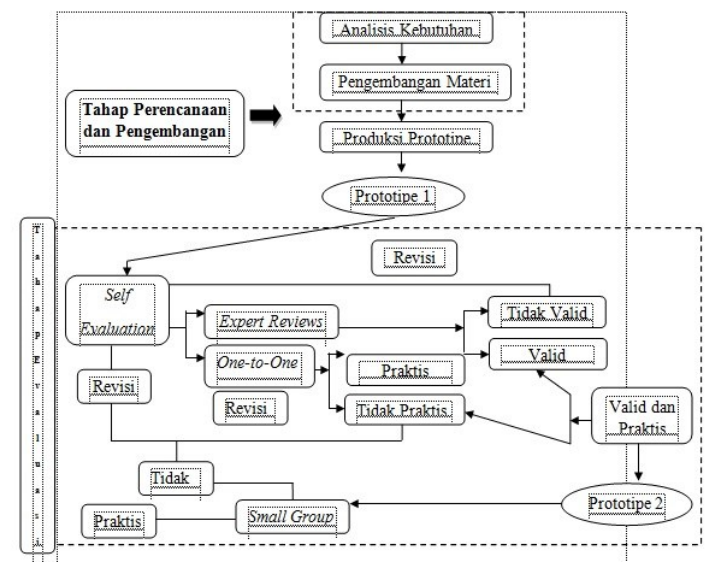

Bagan 2.1. Pengembangan Media Pembelajaran Komik Tema Alam Semesta (Modifikasi dari Rowntree dan Tessmer)

\section{Teknik Pengumpulan Data}

Teknik pengumpulan data yang digunakan dalam penelitian ini adalah sebagai berikut.

Tabel 2.1 Teknik Pengumpulan Data Pada Penelitian Media Komik Tema Alam Semesta

\begin{tabular}{|l|l|l|l|}
\hline No & Kegiatan & $\begin{array}{l}\text { Teknik } \\
\text { Pengumpulan } \\
\text { Data }\end{array}$ & Responden \\
\hline 1 & $\begin{array}{l}\text { Tahap } \\
\text { Perencanaan }\end{array}$ & $\begin{array}{l}\text { 1. Analisis } \\
\text { media dan } \\
\text { materi }\end{array}$ & $\begin{array}{l}\text { Media dan materi } \\
\text { yang digunakan } \\
\text { pada TK Anggrek }\end{array}$ \\
\hline
\end{tabular}

\begin{tabular}{|c|c|c|c|}
\hline & $\begin{array}{l}\text { Analisis } \\
\text { Kebutuhan (pra } \\
\text { penelitian) }\end{array}$ & 2. Wawancara & $\begin{array}{l}\text { Delima, Paud } \\
\text { Mawar, TK N } \\
\text { Pembina } 1 \text { Plg } \\
\text { Guru pada masing- } \\
\text { masing kelas }\end{array}$ \\
\hline 2 & Pengembangan & 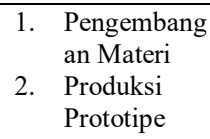 & $\begin{array}{l}\text { Peneliti } \\
\text { Peneliti \& } \\
\text { Ilustrator/Komikus }\end{array}$ \\
\hline 3 & \multicolumn{3}{|l|}{ Evaluasi } \\
\hline & 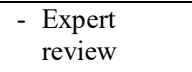 & Walkthrough & $\begin{array}{l}\text { Ahli Media dan } \\
\text { ahli materi }\end{array}$ \\
\hline & - One to one & Observasi & $\begin{array}{l}3 \text { anak kelas B12 } \\
\text { di TK Negeri } \\
\text { Pembina } 1 \\
\text { Palembang }\end{array}$ \\
\hline & - Small group & Observasi & $\begin{array}{l}9 \text { anak kelas B12 } \\
\text { di TK Negeri } \\
\text { Pembina } 1 \\
\text { Palembang }\end{array}$ \\
\hline
\end{tabular}

\section{Walkthrough}

Walkthrough dikutip Anggraini (2015) adalah validasi data yang melibatkan beberapa ahli untuk mengevaluasi produk sebagai dasar untuk merevisi produk awal/prototipe 1 . Walkthrough dilakukan dengan cara memberikan prototipe 1 kepada ahli (validator), yaitu ahli media dan ahli materi untuk dievaluasi. Kemudian validator memberikan masukan kepada peneliti mengenai media yang telah dibuat berupa komik tema alam semesta. Komentar dan saran dari validator dijadikan bahan untuk perbaikan media. Dalam pelaksanaan tahap ini digunakan lembar validasi yang berisi poin-poin yang menjadi tolak ukur untuk ahli media dan materi. Adapun kisi-kisi instrumen validasi materi dan media dapat dilihat pada Tabel 2.2 dan 2.3 di bawah ini

Tabel 2.2 Kisi-Kisi Instrumen Validasi Content/Materi

\begin{tabular}{|l|c|c|}
\hline No & Indikator & Item \\
\hline 1 & Penyajian Materi & $1,2,3,4$ \\
\hline
\end{tabular}




\begin{tabular}{|l|l|l|}
\hline 2 & $\begin{array}{l}\text { Perumusan Ide cerita } \\
\text { dan Pembentukan } \\
\text { Karakter }\end{array}$ & $5,6,7,8$ \\
\hline 3 & $\begin{array}{l}\text { Pemilihan Tema Pada } \\
\text { Media }\end{array}$ & $\begin{array}{l}9,10,11, \\
12\end{array}$ \\
\hline 4 & Keefektifan Materi & $13,14,15$ \\
& &, 16 \\
\hline
\end{tabular}

(Modifikasi Arsyad

$(2017: 222)$

Tabel 2.3 Kisi-Kisi Instrumen Validasi Media

\begin{tabular}{|l|l|l|}
\hline No & \multicolumn{1}{|c|}{ Indikator } & Item \\
\hline 1 & Desain Tampilan & $1,2,3,4$ \\
\hline 2 & Kepraktisan Media & $5,6,7,8$ \\
\hline 3 & Penggunaan bahan & $9,10,1$ \\
& & 1,12 \\
\hline 4 & Keindahan bentuk & 13,14, \\
& Media & 15,16 \\
& \multicolumn{2}{|c|}{ Arsyad } \\
\hline
\end{tabular}

$(2017: 222)$

\subsubsection{Observasi}

Menurut Hadi (1986) yang dikutip oleh Sugiyono (2015:203) observasi adalah suatu proses yang kompleks, suatu proses yang tersusun dari berbagai proses biologis dan psikologis. Hal yang terpenting adalah proses pengamatan dan ingatan. Adapun jenis observasi yang akan dilakukan peneliti yaitu jenis observasi langsung. Observasi langsung merupakan kegiatan dimana peneliti terlibat secara langsung dengan objek atau subjek yang diamati. Observasi dilakukan pada saat tahap one to one dan small grup apakah sudah terlaksana dengan baik saat menggunakan media komik tema alam semesta. Hasil observasi dicatat oleh peneliti pada lembar observasi yang telah disediakan dengan kisi-kisi yang dapat dilihat pada tabel dibawah ini.
Tabel 2.4 Kisi-Kisi Instrumen Observasi Penelitian Aktivitas Anak Terhadap Media Komik Tema Alam Semesta

\begin{tabular}{|c|c|c|}
\hline No & Indikator Kegiatan & $\begin{array}{c}\text { Nomor } \\
\text { Pernyataa } \\
n\end{array}$ \\
\hline 1 & $\begin{array}{l}\text { Menyebutkan macam-macam } \\
\text { manfaat air }\end{array}$ & 1 \\
\hline 2 & $\begin{array}{l}\text { Menjelaskan kembali macam- } \\
\text { macam manfaat tanah }\end{array}$ & 2 \\
\hline 3 & $\begin{array}{l}\text { Menyebutkan macam-macam } \\
\text { manfaat batu }\end{array}$ & 3 \\
\hline 4 & $\begin{array}{l}\text { Membedakan manfaat dari } \\
\text { emas dan perak }\end{array}$ & 4 \\
\hline 5 & $\begin{array}{l}\text { Menjelaskan macam-macam } \\
\text { manfaat matahari }\end{array}$ & 1 \\
\hline 6 & $\begin{array}{l}\text { Membedakan manfaat dari } \\
\text { bulan dan bintang }\end{array}$ & 2 \\
\hline 7 & $\begin{array}{l}\text { Menjelaskan proses } \\
\text { terjadinya siang dan malam }\end{array}$ & 1 \\
\hline 8 & $\begin{array}{l}\text { Menyebutkan macam-macam } \\
\text { penyebab terjadinya banjir }\end{array}$ & 2 \\
\hline 9 & $\begin{array}{l}\text { Menjelaskan dampak dari } \\
\text { letusan gunung berapi }\end{array}$ & 3 \\
\hline 10 & $\begin{array}{l}\text { Menyebutkan penyebab } \\
\text { terjadinya tanah longsor }\end{array}$ & 4 \\
\hline 11 & $\begin{array}{l}\text { Mengurutkan proses terjadinya } \\
\text { pelangi }\end{array}$ & 5 \\
\hline 12 & $\begin{array}{l}\text { Mengurutkan proses terjadinya } \\
\text { hujan }\end{array}$ & 6 \\
\hline
\end{tabular}

\section{Teknik Analisis Data}

\section{Analisis data Walkthrough}

Setelah desain produk selesai, dilakukan validasi oleh ahli media dan ahli materi. Lembar validasi yang diberikan kepada validator dalam bentuk skala Likert. Pernyataan-pernyataan yang diajukan dinilai oleh validator dengan kategori sangat baik (SB), baik (B), cukup (C), dan tidak baik (TB) . Berdasarkan lembar validasi yang telah diisi validator, 
selanjutnya dilakukan penghitungan skor. Seperti terlihat pada tabel 2.5 sebagai berikut :

Tabel 2.5 Kategori Nilai Validasi

\begin{tabular}{|l|l|}
\hline $\begin{array}{l}\text { Kategori } \\
\text { Jawaban }\end{array}$ & $\begin{array}{l}\text { Skor } \\
\text { Pernyataan }\end{array}$ \\
\hline Sangat baik & 4 \\
\hline Baik & 3 \\
\hline Cukup & 2 \\
\hline Tidak Baik & 1 \\
\hline
\end{tabular}

Skor yang diperoleh dari para validator tersebut dihitung rata-ratanya menggunakan rumus:

$$
\begin{array}{ll}
X=\frac{\Sigma \mathrm{x}}{\mathrm{N}} & \text { dengan: } \\
& \mathrm{X}=\text { Nilai rata-rata } \\
& \Sigma \mathrm{x}=\text { Jumlah nilai data } \\
& \mathrm{N}=\text { Banyaknya data }
\end{array}
$$

Selanjutnya, rata-rata yang didapat, dikategorikan seperti pada tabel berikut.

Tabel 2.6 Kategori Tingkat validitas Media

\begin{tabular}{|l|l|}
\hline Rata-Rata & Kategori \\
\hline $3,25-4,00$ & Sangat Valid \\
\hline $2,50-3,24$ & Valid \\
\hline $1,75-2,49$ & Tidak Valid \\
\hline $1,00-1,74$ & Sangat Tidak Valid \\
\hline
\end{tabular}

Skor $\operatorname{Max}=4$

Skor $\operatorname{Min}=1$

$\mathrm{K}=4$

$\mathrm{R}=4-1=3$

$\mathrm{I}=\frac{R}{K}=\frac{3}{1}=0,75$

\section{Analisis Data Observasi}

Hasil observasi terhadap anak selama uji coba pada tahap one to one dan small grup digunakan untuk melihat tingkah laku anak pada saat proses pembelajaran menggunakan media komik tema alam semesta. Data hasil observasi disajikan dalam bentuk tabel, kemudian menghitung nilai hasil observasi dengan menggunakan rumus sebagai berikut :

Nilai persentase $=\frac{\text { Skor Perolehan }}{\text { Skor Maksimal }} \times 100 \%$ (Sunarti \& Rahmawati (2014: 191)

Nilai observasi dikonversikan kedalam kategori yang ditetapkan seperti pada Tabel 2.7 di bawah ini

Skor $\max =4+4+4+4$

Skor $\min =1+1+1+1$

NA $\max =\frac{16}{16} \times 100 \%=100$

$\mathrm{NA} \min =\frac{4}{16} \times 100 \%=25$

$\mathrm{K}=4$

$\mathrm{R}=100-25=75$

$\mathrm{I}=\frac{R}{K}=\frac{75}{4}=18,75 \sim 19$

Tabel 2.7 Kategori Nilai Hasil Observasi Anak Terhadap Penggunaan Media Komik Tema Alam Semesta

\begin{tabular}{|l|l|}
\hline Skor & Kategori \\
\hline $80-100$ & Berkembang Sangat Baik \\
\hline $61-80$ & Berkembang Sesuai Harapan \\
\hline $41-60$ & Mulai Berkembang \\
\hline $21-40$ & Belum Berkembang \\
\hline \multicolumn{2}{|c|}{ (Amirono \& Daryanto (2016:126) } \\
\hline
\end{tabular}

\section{HASIL PENELITIAN DAN PEMBAHASAN}

Hasil penelitian yang berjudul pengembangan media pembelajaran komik tema alam semesta dilakukan menggunakan tiga tahapan yaitu perencanaan, pengembangan dan evaluasi. Peneliti mengembangkan satu produk komik tema alam semesta. Berikut ini adalah uraian 
tahapan dalam pengembangan media komik tema alam semesta.

Tahap Perencanaan, pada tahapan ini yang pertama kali dilakukan adalah menganalisis media dan materi. Analisis media dan materi dilakukan untuk mengidentifikasi masalah dan mengetahui karakteristik murid, yaitu dengan menganalisis media yang dipakai murid sekarang dan materi yang diberikan oleh guru kepada murid, media dan materi yang diamati berhubungan dengan perkembangan bahasa anak usia 5-6 tahun dan mendeskripsikan kriteria buku komik yang baik untuk anak yang sesuai dengan tema alam semesta yang ada di kurikulum.

$$
\text { Tahap Pengembangan, }
$$

Pengembangan Materi / Membuat Materi. Adapun materi yang diberikan pada anak yaitu tema alam semesta yang terdiri dari tiga subtema yaitu benda-benda alam, benda-benda langit, dan gejala alam. Disetiap subtema terdiri dari beberapa subsubtema, pada subtema benda-benda alam berisi tentang jenis benda-benda alam yaitu air,tanah,batu, emas dan perak beserta manfaatnya. Pada subtema benda-benda langit berisi tentang jenis benda-benda langit yaitu matahari, bulan dan bintang beserta manfaatnya. Pada subtema gejala alam berisi tentang macam-macam gejala alam yaitu siang dan malam, banjir, gunung meletus, tanah longsor, pelangi, dan hujan. (2) menulis cerita, Agar materi tema alam semesta mudah dipahami oleh anak, maka dibuatlah cerita tentang satu keluarga yang terdiri dari lima orang yaitu bapak, ibu, rizki, anisa, dan dimas. Garis besar komik ini mengambil cerita tentang kehidupan sehari-hari sehingga anak mudah memahami jalan setiap cerita yang ada pada komik, pendapat ini sama halnya yang dikatakan oleh Noviana (2013) yaitu bagi anak usia dini mendengarkan cerita yang menarik dan dekat dengan lingkungannya merupakan kegiatan yang mengasyikan. (3) Menentukan Format dan Tata Letak, Format kertas yang digunakan adalah portrait. Ukuran kertas adalah $16 \mathrm{~cm} \times 23$ $\mathrm{cm}$ dengan jenis kertas bagian isi menggunakan Art Paper 120 dan untuk cover menggunakan Art Carton 230 di mana penempatan gambar dan tulisan disesuaikan dengan isi cerita.

Produksi Prototipe, setelah melakukan penyusunan draft cerita, langkah selanjutnya adalah produksi prototipe. Draft cerita yang telah disusun telah dilengkapi dengan gambar dan disunting untuk mendapatkan cerita yang sesuai dengan materi tema alam semesta untuk anak usia 5-6 tahun dan warna yang digunakan pada gambar adalah warna yang cerah, agar anak tertarik untuk membaca buku komik. Senada dengan Hurlock (2000) yang dikutip oleh Ramliyana (2016) bahwa anakanak usia sekolah menyukai komik karena beberapa hal diantaranya adalah karena gambar dalam komik bewarna-warni dan cukup sederhana untuk dimengerti anakanak. Peneliti memproduksi satu produk berupa komik dengan judul Mari Mengenal Alam Semesta. Hasil keseluruhan tahap pengembangan ini adalah prototipe 1 .

Pada tahap pengembangan juga disiapkan perangkat evaluasi yang digunakan untuk menilai komik tema alam semesta yang telah dibuat dilihat dari segi content/materi dan konstruk/desain buku. Seperti yang dikemukakan oleh Haviz (2013) yaitu Indikator-indikator yang digunakan untuk menyimpulkan produk pembelajaran yang dikembangkan valid adalah validitas isi dan validitas konstruk. Perangkat evaluasi berupa lembar validasi content/materi, konstruk/desain buku, dan lembar observasi untuk menilai tingkah laku anak terhadap penggunaan komik tema alam semesta. Sebelum digunakan, perangkat evaluasi tersebut terlebih dahulu diperiksa oleh dosen pembimbing.

Tahap Evaluasi, dari cerita yang telah diilustrasikan dalam bentuk gambar yang telah didesain disebut sebagai prototipe 1 . Selanjutnya, Prototipe 1 dilakukan tahap self evaluation. Setelah self evaluation dilakukan kemudian lanjut ke tahap expert review yang terdiri dari ahli content/materi dan desain. Selain itu, dilakukan uji coba one-to-one evaluation pada 3 orang anak 
kelompok B small group evaluation pada 9 orang anak kelompok B. Hasil dari masingmasing tahap evaluasi sesuai dengan model evaluasi formatif Tessmer yaitu sebagai berikut.

Tahap Expert Review, merupakan tahap untuk melihat validitas secara content/materi dan desain media komik dengan materi tema alam semesta yang dikembangkan oleh peneliti. Tahap ini bertujuan untuk mendapatan materi dan desain tema alam semesta yang valid. Dalam proses validasi peneliti menggunakan metode walkhtrough, yaitu setiap lembar prototype diberikan kepada pakar dan setiap lembar prototype tersebut divalidasi. Para pakar/ahli yang menjadi validator prototype 1 adalah :(1) Dra. Yetty Rahelly, M.Pd, Ph.D. Dosen Universitas Sriwijaya. Sebagai validator media (2) Mahyumi Rantina, M.Pd. Dosen Universitas Sriwijaya. Sebagai validator materi. Hasil validasi yang dilakukan oleh ahli dapat dilihat pada Tabel 3.1 dan 3.2 berikut ini.

Tabel 3.1 Hasil Penilaian Validator Content/Materi

\begin{tabular}{|l|l|l|l|l|}
\hline No & Indikator & $\begin{array}{l}\text { Nomor } \\
\text { Pernyat } \\
\text { aan }\end{array}$ & $\begin{array}{l}\text { Jumlah } \\
\text { Pernyat } \\
\text { aan }\end{array}$ & $\begin{array}{l}\text { Rekapit } \\
\text { ulasi } \\
\text { Nilai }\end{array}$ \\
\cline { 3 - 4 } & $\begin{array}{l}\text { Media } \\
\text { Komik } \\
\text { Tema } \\
\text { Alam } \\
\text { Semesta }\end{array}$ \\
\hline 2 & $\begin{array}{l}\text { Penyajian } \\
\text { Materi }\end{array}$ & $1,2,3,4$ & 4 & 15 \\
\hline $\begin{array}{l}\text { Perumusa } \\
\text { Ide } \\
\text { Cerita } \\
\text { dan } \\
\text { Pembent } \\
\text { ukan } \\
\text { Karakter }\end{array}$ & $5,6,7,8$ & 4 & 16 \\
\hline 3 & $\begin{array}{l}\text { Pemiliha } \\
\text { n Tema } \\
\text { Pada } \\
\text { Media }\end{array}$ & $9,10,1$ & 4 & 14 \\
\hline
\end{tabular}

\begin{tabular}{|l|l|l|l|l|}
\hline 4 & $\begin{array}{l}\text { Keefektif } \\
\text { an } \\
\text { Materi }\end{array}$ & $\begin{array}{l}13,14, \\
15,16\end{array}$ & 4 & 16 \\
\hline Jumlah & $\mathbf{1 6}$ & $\mathbf{6 1}$ \\
\hline \multicolumn{2}{|c|}{ Skor Rata-Rata } & \multicolumn{2}{|c|}{ Sangat Valid } \\
\hline \multicolumn{2}{|c|}{ Kategori } & \multicolumn{2}{|c|}{} \\
\hline
\end{tabular}

Dari tabel diatas dapat dilihat pada indikator penyajian materi, untuk nomor pernyataan 1,2,3,4 jumlah nilai yang didapat adalah 15. Pada indikator perumusan ide cerita dan pembentukan karakter, untuk nomor pernyataan 5,6,7,8 jumlah nilai yang didapat adalah 16 . Pada indikator pemilihan tema pada media, untuk nomor pernyataan 9,10,11,12 jumlah nilai yang didapat adalah 14 . Pada indikator keefektifan materi untuk nomor pernyataan 13,14,15,16 jumlah nilai yang didapat adalah 16. Jadi setelah hasil nilai dari keempat indikator tersebut ditambah dan dibagi, hasil rata-rata nya adalah 3,81 dengan kategori sangat valid.

Tabel 3.2 Hasil Penilaian Validator Media/Desain

\begin{tabular}{|l|l|l|l|l|}
\hline No & Indikator & $\begin{array}{l}\text { Nomor } \\
\text { Pernya } \\
\text { taan }\end{array}$ & $\begin{array}{l}\text { Jumlah } \\
\text { Pernyat: } \\
\text { an }\end{array}$ & $\begin{array}{l}\text { Rekapitz } \\
\text { lasi Nilai }\end{array}$ \\
\cline { 3 - 5 } & $\begin{array}{l}\text { Media } \\
\text { Komik } \\
\text { Tema } \\
\text { Alam } \\
\text { Semesta }\end{array}$ \\
\hline 1 & $\begin{array}{l}\text { Desain } \\
\text { tampilan }\end{array}$ & $\begin{array}{l}1,2,3, \\
4\end{array}$ & 4 & 15 \\
\hline 3 & $\begin{array}{l}\text { Keprakti } \\
\text { san } \\
\text { media }\end{array}$ & $\begin{array}{l}5,6,7, \\
8\end{array}$ & 4 & 15 \\
\hline $\begin{array}{l}\text { Penggun } \\
\text { aan } \\
\text { bahan }\end{array}$ & $\begin{array}{l}9,10,1 \\
1,12\end{array}$ & 4 & 14 \\
\hline 4 & $\begin{array}{l}\text { Keindah } \\
\text { an } \\
\text { bentuk } \\
\text { media }\end{array}$ & $\begin{array}{l}13,14, \\
15,16\end{array}$ & 4 & 14 \\
\hline
\end{tabular}




\begin{tabular}{|c|c|c|}
\hline Jumlah & 16 & 58 \\
\hline Skor Rata-Rata & \multicolumn{2}{|c|}{3,62} \\
\hline Kategori & Sangat Valid \\
\hline
\end{tabular}

Dari tabel diatas dapat dilihat pada indikator desain tampilan, untuk nomor pernyataan 1,2,3,4 jumlah nilai yang didapat adalah 15. Pada indikator kepraktisan media, untuk nomor pernyataan 5,6,7,8 jumlah nilai yang didapat adalah 15. Pada indikator penggunaan bahan, untuk nomor pernyataan $9,10,11,12$ jumlah nilai yang didapat adalah 14. Pada indikator keindahan bentuk media untuk nomor pernyataan $13,14,15,16$ jumlah nilai yang didapat adalah 14. Jadi setelah hasil nilai dari keempat indikator tersebut ditambah dan dibagi, hasil rata-rata nya adalah 3,62 dengan kategori sangat valid.

Tabel 3.3 Rekapitulasi Hasil Penilaian Validator

\begin{tabular}{|l|l|l|}
\hline \multirow{2}{*}{ No } & \multirow{2}{*}{ Validasi } & Rekapitulasi Nilai \\
\cline { 3 - 3 } & & $\begin{array}{l}\text { Media Komik Tema } \\
\text { Alam Semesta }\end{array}$ \\
\hline 1 & Content/mat & 3,81 \\
\hline 2 & Desain & 3,62 \\
\hline \multicolumn{2}{|c|}{ Rata-Rata } & $\mathbf{3 , 7 2}$ \\
\hline \multicolumn{2}{|c|}{ Kategori } & Sangat Valid \\
\hline
\end{tabular}

Berdasarkan data didapatkan bahwa rata-rata hasil validasi expert review untuk aspek content/materi media komik tema alam semesta sebesar 3,81 (kategori sangat valid) dan untuk desain media komik tema alam semesta sebesar 3,62 (kategori sangat valid) sehingga didapat rata-rata hasil validasi ahli untuk media komik tema alam semesta adalah 3,72 (kategori sangat valid). Dengan demikian,media komik tema alam semesta yang dikembangkan ini layak untuk diuji coba.

Setelah dilakukan tahap expert review terhadap prototipe 1 , selanjutnya dilakukan tahap one-to-one evaluation yang bertujuan untuk melihat kepraktisan prototipe 1 yang telah divalidasi oleh ahli. Tahap ini melibatkan tiga orang anak dan mereka secara bersamaan menggunakan prototipe 1. Pada saat proses pembelajaran menggunakan prototipe 1, mereka diobservasi oleh peneliti yang bertujuan untuk melihat dan menilai secara langsung aktivitas dan tingkah laku anak terhadap prorotipe 1. Data hasil observasi anak dapat dilihat dibawah ini.

Tabel 3.4 Analisis Data Observasi Anak pada Tahap One-to-One Evaluation

\begin{tabular}{|c|c|c|c|}
\hline No & $\begin{array}{l}\text { Subtema Benda- } \\
\text { Benda Alam }\end{array}$ & $\begin{array}{c}\text { Rata-Rata } \\
(\%)\end{array}$ & Kategori \\
\hline \multirow{3}{*}{1} & Indikator & & \\
\hline & $\begin{array}{l}\text { 1. } \begin{array}{l}\text { Menyebutkan } \\
\text { macam-macam } \\
\text { manfaat air }\end{array} \\
\text { 2. Menjelaskan } \\
\text { kembali macam- } \\
\text { macam manfaat } \\
\text { tanah } \\
\text { 3. Menyebutkan } \\
\text { macam-macam } \\
\text { manfaat batu } \\
\text { 4. Membedakan } \\
\text { manfaat dari } \\
\text { emas dan perak }\end{array}$ & $81,3 \%$ & BSB \\
\hline & $\begin{array}{l}\text { Subtema Benda- } \\
\text { Benda Langit }\end{array}$ & \multirow[t]{2}{*}{$\begin{array}{c}\text { Rata-Rata } \\
(\%)\end{array}$} & \multirow[t]{2}{*}{ Kategori } \\
\hline \multirow{3}{*}{2} & Indikator & & \\
\hline & $\begin{array}{ll}\text { 1. } & \text { Menjelaskan } \\
\text { macam-macam } \\
\text { manfaat matahari } \\
\text { 2. Membedakan } \\
\text { manfaat dari } \\
\text { bulan dan bintang }\end{array}$ & $79,2 \%$ & BSH \\
\hline & $\begin{array}{c}\text { Subtema Gejala } \\
\text { Alam }\end{array}$ & \multirow[t]{2}{*}{$\begin{array}{c}\text { Rata-Rata } \\
(\%)\end{array}$} & \multirow[t]{2}{*}{ Kategori } \\
\hline \multirow[b]{2}{*}{3} & Indikator & & \\
\hline & 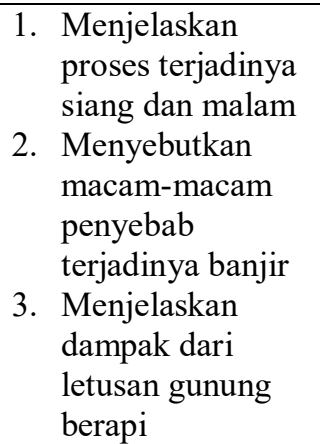 & $79,2 \%$ & BSH \\
\hline
\end{tabular}




\begin{tabular}{|l|l|l|}
\hline 4. & Menyebutkan \\
penyebab & \\
terjadinya tanah & \\
longsor & \\
5. & Mengurutkan \\
proses terjadinya & \\
pelangi & \\
6. & Mengurutkan \\
proses terjadinya & \\
hujan & & \\
\hline
\end{tabular}

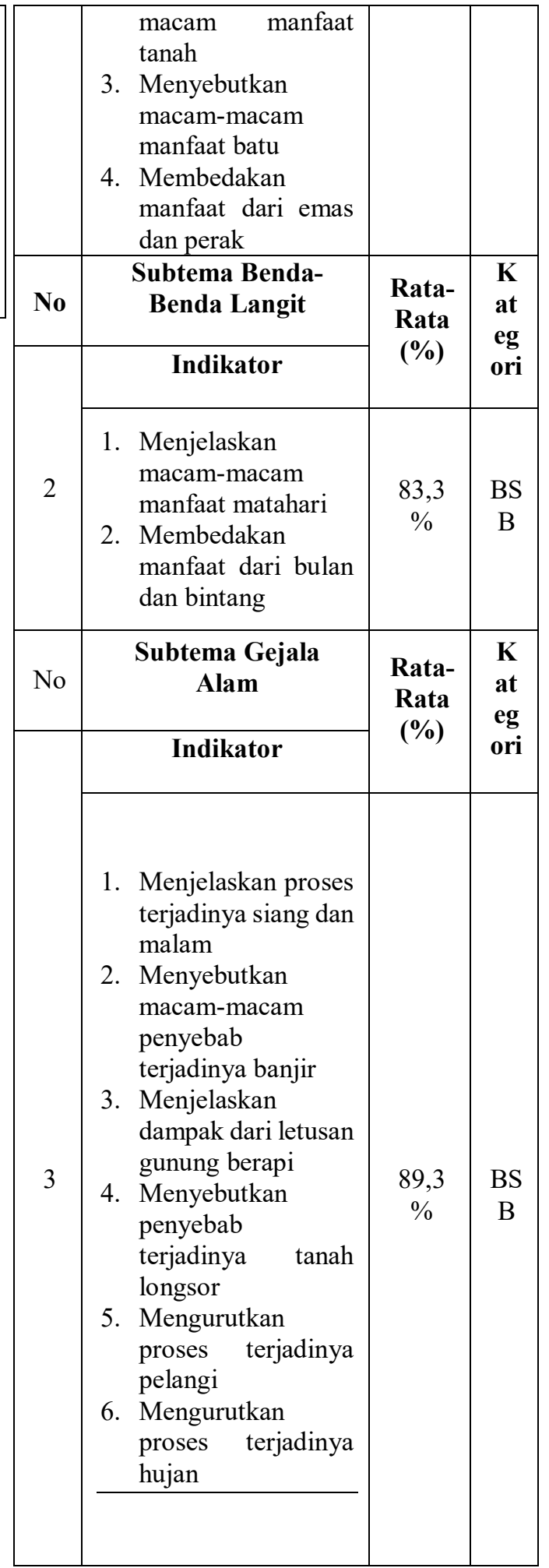

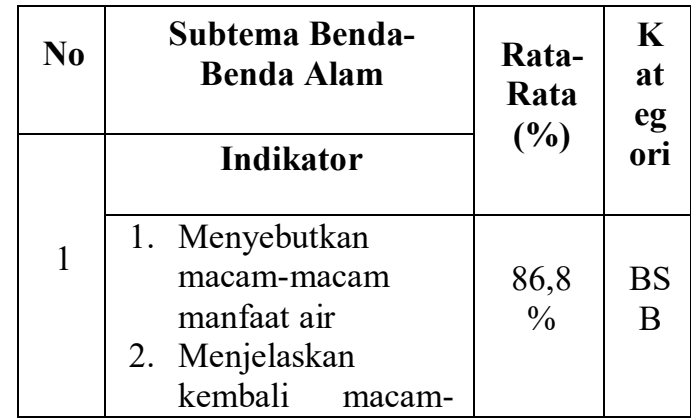


sebesar $83,3 \%$ (kategori berkembang sangat baik), Subtema Gejala Alam sebesar 89,3\% (kategori berkembang sangat baik), sehingga dapat disimpulkan bahwa penggunaan media komik tema alam semesta memiliki kriteria praktis bagi anak.

\section{Pembahasan}

Penelitian Pengembangan ini bertujuan untuk mengembangkan media komik tema alam semesta untuk anak kelompok B di TK Negeri Pembina 1 Palembang. Dalam hal ini peneliti mengembangkan satu buku komik yang mengambil tema semester dua yaitu tema alam semesta, karena disesuaikan dengan waktu pelaksanaan penelitian, terdiri dari tiga subtema, yaitu (1) subtema benda-benda alam (2) subtema benda-benda langit, dan (3) subtema gejala alam. Penelitian ini dilakukan pada tanggal 05 April 2017 hingga 11 April 2017 dengan subjek penelitian anak kelompok B12 di TK Negeri Pembina 1 Palembang dan objek penelitian berupa media komik tema alam semesta. Penelitian ini menggunakan kombinasi model pengembangan Rowntree dan model evaluasi formatif Tessmer. Model pengembangan Rowntree terdiri dari tiga tahap, yaitu tahap perencanaan, tahap pengembangan dan tahap evaluasi. Pemilihan model pengembangan Rowntree dalam penelitian ini karena model pengembangan Rowntree merupakan salah satu model yang berorientasi pada produk khususnya untuk memproduksi buku atau bahan ajar. Selanjutnya, untuk tahap evaluasi digunakan model evaluasi Tessmer yang terdiri dari lima tahap, yaitu tahap self evaluation, expert review, one-to-one evaluation, small group evaluation dan field test, namun pada penelitian ini, hanya sampai pada tahap small grup saja, dikarenakan penelitian ini hanya menguji kevalidan dan kepraktisan dari media komik, tidak sampai menguji efek potensial bagi anak.

Pada tahap perencanaan dilakukan analisis media, materi dan melakukan wawancara dengan guru kelas untuk mengetahui masalah dan kebutuhan serta perkembangan anak. Dalam hal ini, peneliti akan mengembangkan media komik tema alam semesta karena belum tersedia di TK Negeri Pembina 1 Palembang dengan merujuk pada tujuan Kurikulum 2013. Materi yang diberikan yaitu dengan tema alam semesta yang terdiri dari tiga subtema, subtema benda-benda alam (air, tanah, batu, emas dan perak), subtema benda-benda langit (matahari, bulan dan bintang), dan subtema gejala alam (siang dan malam, banjir, gunung meletus, tanah longsor, pelangi dan hujan). Karena, tidak tersedianya media pembelajaran yang inovatif dalam memberikan materi untuk tema alam semesta, padahal materi alam semesta memiliki banyak sekali cakupan pembelajarannya, sehingga anak tidak antusias dalam pembelajaran terutama pada aspek bahasa.

Untuk itu diperlukan sebuah media komik yang dapat menampilkan pembelajaran yang menyenangkan bagi anak sehingga anak lebih tertarik, antusias dan dapat menambah ilmu pengetahuan anak-anak sesuai dengan kehidupan seharihari. Seperti yang dikemukakan oleh Sudjana dan Rivai (2011: 68) yang dikutip oleh Azizah \& Khanafiyah (2014) menyatakan bahwa media komik dalam proses belajar mengajar menciptakan minat para peserta didik, mengefektifkan proses belajar mengajar, dapat meningkatkan minat belajar dan menimbulkan minat apresiasinya. Senada dengan pendapat diatas, menurut Rohani (2014:78) bahwa peranan pokok dari buku komik adalah kemampuannya dalam menciptakan minat peserta didik. Oleh karena itu, peneliti mengembangkan media komik tema alam semesta yang dikemas dalam sebuah cerita kemudian divisualisasikan ke dalam gambar dengan warna-warna yang menarik bagi anak sehingga anak lebih mudah mengerti dan memahami materi yang ada pada komik tersebut.

Setelah dilakukan tahap perencanaan, selanjutnya peneliti melakukan tahap 
pengembangan. Tahap pengembangan terdiri dari dua tahap yaitu pengembangan materi dan produksi prototipe. Pada tahap ini juga peneliti menyiapkan perangkat evaluasi. Sebelum digunakan perangkat evaluasi terlebih dahulu dikonsultasikan dengan dosen pembimbing. Hasil dari tahap pengembangan ini adalah prototipe 1 . Media komik yang telah dikembangkan kemudian divalidasi oleh para ahli (expert review). Tahap expert review ini bertujuan untuk mengetahui materi dan desain cerita tema alam semesta yang valid. Dalam media komik ini, validasi ahli meliputi validasi content/materi dan desain media komik. Prototipe 1 yang telah didesain kemudian dikonsultasikan dengan dosen pembimbing skripsi dan kemudian divalidasi oleh ahli.

Secara keseluruhan, nilai rata-rata hasil validasi Expert Review untuk materi yaitu sebesar 3,81 (kategori sangat valid) dan untuk desain media yaitu sebesar 3,62 (kategori sangat valid) sehingga didapat nilai rata-rata hasil validasi ahli untuk media komik tema alam semesta adalah 3,72 (kategori sangat valid).

Dengan demikian, media komik tema alam semesta yang dikembangkan peneliti dapat digunakan pada tahap uji coba selanjutnya. Berdasarkan saran dari validator maka terdapat beberapa revisi dari prototipe 1 . Selanjutnya, media komik tema alam semesta yang telah divalidasi kemudian diujicoba pada tahap one-to-one evaluation. Tahap one-to-one evaluation bertujuan untuk melihat kepraktisan prototipe 1 yang telah divalidasi oleh ahli. Tahap ini melibatkan tiga orang anak dan mereka secara bersamaan menggunakan media komik tema alam semesta.Pada tahap ini guru yang menceritakan media komik tersebut, peneliti hanya membantu saja, lalu anak mendengarkan dan menjawab pertanyaan yang diberikan oleh guru mengenai cerita yang telah mereka dengar. Setelah anak menggunakan prototipe 1, peneliti mengobservasi anak pada saat pembelajaran yang bertujuan untuk melihat penilaian mereka terhadap prototipe 1 .
Nilai persentase rata-rata hasil observasi anak terhadap penggunaan media komik tema alam semesta pada tahap one-to-one evaluation pada subtema benda-benda alam sebesar $81,3 \%$ (kategori berkembang sangat baik), subtema benda-benda langit sebesar $79,2 \%$ (kategori berkembang sesuai harapan), subtema gejala alam sebesar $79,2 \%$ (kategori berkembang sesuai harapan), sehingga dapat disimpulkan bahwa penggunaan media komik tema alam semesta tergolong praktis. Hasil revisi dari prototipe 1 didapatkan prototipe 2 .

Untuk melihat kepraktisan buku cerita matematika dilakukan uji coba prototipe 2 pada anak dalam tahap small group evaluation. Tahap ini dilaksanakan untuk melihat kepraktisan protipe 2 . Uji coba prototipe 2 ini dilakukan kepada 9 orang anak kelompok B12 di TK Negeri Pembina 1 Palembang. Pada Tahap ini juga guru yang menceritakan media komik tersebut lalu anak mendengarkan dan menjawab pertanyaan yang diberikan oleh guru seperti manfaat air, manfaat tanah, dan bagaimana proses terjadinya hujan. Pada uji coba di tahap small group evaluation, anak diobservasi kembali. Nilai rata-rata persentase hasil observasi tahap small group evaluation pada subtema bendabenda alam sebesar 86,8\% (kategori berkembang sangat baik), subtema bendabenda langit sebesar 83,3\% (kategori berkembang sangat baik), subtema gejala alam sebesar 89,3\% (kategori berkembang sangat baik), ini berarti prototipe 2 yang dikembangkan peneliti sudah praktis. Penelitian ini hanya sampai pada tahap small group saja karena penelitian ini hanya menguji kevalidan dan kepraktisan media komik dan tidak sampai pada menguji efek potensial dari media komik tersebut.

Berdasarkan deskripsi dan analisis data hasil penelitian didapatkan bahwa produk media pembelajaran komik yang dikembangkan sangat valid dan praktis terhadap anak, sehingga dapat digunakan sebagai media pembelajaran pada semester dua tema alam semesta untuk anak usia 5-6 tahun. 


\section{KESIMPULAN}

Berdasarkan penelitian yang telah dilakukan tentang pengembangan media pembelajaran komik tema alam semesta dapat disimpulkan sebagai berikut. Media pembelajaran komik tema alam semesta yang dikembangkan dinyatakan sangat valid berdasarkan hasil validasi para ahli (expert review) yang terdiri dari ahli content/materi dan desain dengan rata-rata hasil sebesar 3,72 (kategori sangat valid), sehingga media komik tema alam semesta ini layak digunakan sebagai media untuk pembelajaran tema alam semesta. Setelah itu dilanjutkan pada tahap one-to-one evaluation diperoleh nilai observasi anak terhadap penggunaan media komik tema alam semesta dengan rata-rata hasil pada subtema benda-benda alam sebesar $81,3 \%$ (kategori berkembang sangat baik), subtema benda-benda langit sebesar 79,2\% (kategori berkembang sesuai harapan), subtema gejala alam sebesar $79,2 \%$ (kategori berkembang sesuai harapan). Dan hasil nilai observasi anak terhadap penggunaan media komik tema alam semesta pada tahap small group evaluation mendapatkan rata-rata pada subtema benda-benda alam sebesar $86,8 \%$ (kategori berkembang sangat baik), subtema benda-benda langit sebesar 83,3\% (kategori berkembang sangat baik), subtema gejala alam sebesar 89,3\% (kategori berkembang sangat baik) sehingga berdasarkan hasil one-to-one evaluation dan small group evaluation dapat dinyatakan bahwa media komik tema alam semesta yang dikembangkan telah teruji praktikalitasnya.

\section{DAFTAR PUSTAKA}

Amirono, M.T., \& Daryanto. (2016). Evaluasi dan Penilaian Pembelajaran Kurikulum 2013. Yogyakarta: Gava Media.

Asmariani. (2016). Konsep Media Pembelajaran PAUD. Jurnal AlAfkar. V (1) : 32 .

Azizah, N., Khanafiyah, S. (2014). Pengaruh Komik Sains Dalam
Pembelajaran Ipa Terhadap

Pengembangan Karakter Siswa Di Kecamatan Semarang Tengah. Unnes Physics Education Journal. 3 (3): 35. Daryanto.(2016).Media

Pembelajaran.Yogyakarta:Gava Media.

Haviz, M. (2013). Research And Development; Penelitian Di Bidang Kependidikan Yang Inovatif, Produktif Dan Bermakna. Ta'dib. 16 (1): 30 .

Juliati, A D. (2014). Peningkatan Motivasi Menulis Anak Usia 5-6 Tahun Melalui Penggunaan Media Komik. Jurnal Ilmiah VISI P2TK PAUDNI. 9 (2) : 128.

Noviana L. (2013). Pengaruh Metode Bercerita Terhadap Kemampuan Menyimak Pada Anak Kelompok Bermain Tunas Bangsa Di Ds.Wotansari Kec.Balongpanggang Kab.Gresik. Jurnal Mahasiswa Unesa. 2 (1) : 3 \& 6.

Permendikbud No 146. (2014). Kurikulum 2013 Pendidikan Anak Usia Dini.Jakarta: Permendikbud.

Prawiradilaga, D. S. (2015). Prinsip Desain Pembelajaran (Instructional Design Principles). Jakarta: Kencana Prenada Media Group.

Rohani, A.(2014). Media Instruksional Edukatif.Jakarta:Rineka Cipta.

Ramliyana, R. (2016). Penerapan Media Komik Pada Pembelajaran BIPA (Studi Kasus Pada Peserta Korea Tingkat Pemula di

Universitas Trisakti Jakarta). Jurnal SAP. 1 (1): 3 .

Setiawan.(2013). Peningkatan

Keterampilan Bercerita Menggunakan

Media Komik Strip Bermuatan NilaiNilai Pendidikan Karakter Pada Siswa Kelas II Mi Rifaiyah Limpung Batang. Skripsi. Semarang: Fakultas Bahasa dan Seni Unnes.

Sudarti. (2017). Pemanfaatan Media Komik Dan Metode Latihan Terbimbing Untuk Meningkatkan Keterampilan Menulis Cerpen Siswa 
Kelas X-1 SMA N I Cepiring

Semester 2 Tahun Pelajaran

2015/2016. Majalah Ilmiah Inspiratif.

2 (3): 3.

Sugiyono.(2015).Metode Penelitian \&

Pengembangan Research and

Development.Bandung:Alfabeta.

Sunarti \& Rachmawati, S. (2014).

Penilaian dalam Kurikulum 2013

Membantu Guru dan Calon Guru

Mengetahui Langkah-Langkah

Penilaian Pembelajaran. Yogyakarta:

C.V Andi Offset.

Tessmer, M. (1993). Planning and

Conducting Formative Evaluation.

London: Kogan Page 